\title{
Grywalizacja jako sposób radzenia sobie z brakiem motywacji wśród studentów
}

\begin{abstract}
The purpose of this article is to characterize gamification as an increasingly popular contemporary method of teaching, which is part of the StudentCentered Learning trend. The SCL philosophy, which promotes studentcentered approach as the central issue of the learning process, indicates gamification as one of the most effective and the most interesting method of motivating students to be put in the effort in gaining knowledge and derive satisfaction from their achievements in the scientific field. As indicated by the authors, finding the motivation and maintaining it at an adequate level in the process of teaching, is not an easy task, and the problem posed by its absence is becoming more common in Polish and European higher education system. This evaluation is confirmed by the studies of the authors within domestic and foreign literature. The most common causes of amotivation, presented in the article, could be gradually solved just through gamification - teaching methodology, which uses the game mechanics. Gamification, based on the teaching through activating students, encouraging them to a self-activity, a creative rivalry and a cooperation, is
\end{abstract}

1 Magdalena Kędziora, Wydział Zarządzania i Komunikacji Społecznej, Uniwersytet Jagielloński, Polska, magdalena2.kedziora@uj.edu.pl.

2 Marta Stańczyk, Wydział Zarządzania i Komunikacji Społecznej, Uniwersytet Jagielloński, Polska,marta1.stanczyk@uj.edu.pl.

${ }^{3}$ Wojciech Wychowaniec, Wydział Zarządzania i Komunikacji Społecznej, Uniwersytet Jagielloński, Polska, wojciech.wychowaniec@uj.edu.pl. 
nowadays increasingly used in an academic field, where the authors have found numerous interesting examples. The authors of the text are outlining the principles and advantages of using gamification, the potential areas of application as well as interesting projects with its use. They also postulate to change the current paradigm of teaching by replacing the often inefficient 'feeding' teaching methods of transmitting knowledge with more active form, wherein gamification is fully applicable.

\section{Keywords:}

gamifiaction, Student-Centered Learning, motivation, the mechanics of gaming, higher education, activating strategies

Brak motywacji studentów jest jednym z podstawowych problemów, jakie napotykają w czasie swojej praktyki dydaktycznej nauczyciele akademiccy. Zwiększenie jej poziomu nie jest celem samym w sobie i nie wiąże się jedynie z dynamiką zajęć, ale uzależnia wyniki kształcenia - „sprzyja ona koncentracji na zadaniach dydaktycznych, wysiłkowi intelektualnemu i wytrwałości w obliczu przeciwności” (Petty, 2010). Rolę motywacji powinien uświadamiać sobie każdy dydaktyk, mierząc się w czasie swojej pracy z jej brakiem, a także biorąc pod uwagę długoterminowe efekty kształcenia.

Ten sposób myślenia jest szczególnie bliski osobom inspirującym się nowym paradygmatem nauczania, odchodzącym od metod podawczych. Student-Centered Learning (SCL) nie jest konkretną metodą czy techniką uczenia. „Nauczanie koncentrujące się na osobach studiujących definiowane jest jako: opierające się na własnej motywacji [podkr. aut.] oraz potrzebach edukacyjnych studenta” (Grzymała-Moszczyńska, Kwiecień, Rataj, Barzykowski, 2013, s. 33). Badacze dodają, że „SCL ma się przyczyniać do wzmocnienia motywacji do nauki [podkr. aut.] i głębszego zrozumienia sytuacji problemowych” (Grzymała-Moszczyńska i in., 2013, s. 35). Bez wątpienia kwestia motywacji jest jednym z centralnych zagadnień w tym paradygmacie, istotnym o tyle, że pozwala na bardziej efektywne kształcenie. W tradycyjnym systemie nauczania dominowała motywacja zewnętrzna, opierająca się na systemie nagród (sukcesy, pochwała, dobre stopnie itd.) i kar (porażki, konieczność poprawiania stopni, brak akceptacji nauczyciela i kolegów itd.), które możemy rozpatrywać w kategoriach behawioralnych jako wzmocnienia. Osoba ucząca się odgrywa w tym procesie pasywną rolę, a jej osobowe cechy nie są istotne, gdyż jest - jak można to określić za Davidem Rie- 
smanem (2011) - zewnątrzsterowna. Celnie zdiagnozowana przez amerykańskiego socjologa współczesność wymaga modyfikacji tradycyjnego systemu nauczania i włączenia weń metod aktywizujących w celu rozwoju motywacji wewnętrznej. Jak zauważają Baeten, Dochy, Struyven, Parmentier i Vabderbruggen (2016, s. 46), studenci najczęściej przejawiają podejście strategiczne, dostosowując się do oczekiwań, dlatego też początkowy opór wobec większych oczekiwań wykładowcy można przełamać metodycznie podchodząc do zagadnienia motywacji, czego doskonały przykład stanowią techniki grywalizacji, będące przedmiotem rozważań niniejszego artykułu.

\section{MOTYWACJA - PODSTAWOWE KONCEPCJE I JEJ ROLA W PROCESIE NAUCZANIA}

Philip Zimbardo (1988, s. 312-313) określa motywację jako przyczyny zachowania czy raczej zmiany zachowania. Jest to zmienna pośrednicząca, ukierunkowująca jednostkę na konkretny cel i funkcjonująca na kontinuum - między fizjologią a psychologią. Amerykański psycholog podaje przykład drużyn sportowych: mimo porównywalnych umiejętności, wygrywa ta, która chce wygrać, czyli posiada większą motywację. Inny przykład ze świata sportu, który równie łatwo można odnieść do sytuacji studentów, podaje Russell G. Geen (1999, s. 63), przywołując badania kolarzy: osiągali oni lepsze wyniki, gdy jechali w grupie. Te badania wiązane są z motywacją społeczną, czyli taką, która zachodzi w warunkach współdziałania lub przy audytorium - jak w przypadku sali wykładowej.

Obecność innych ludzi może mieć na nas pobudzający lub hamujący wpływ uznaje się zwykle, że pierwszy zachodzi w prostszych sytuacjach. Mamy wtedy do czynienia z facylitacją społeczną. Przy wykonywaniu trudniejszych zadań pojawić się może tzw. efekt Ringelmanna, czyli inhibicja, utrata motywacji w okolicznościach społecznych, związana z zagadnieniem próżniactwa społecznego i „strategią chowania się w tłumie”. Jak podkreśla jednak Geen, nie zawsze chodzi o warunki pracy w grupie, lecz także rodzaj zadania - jeśli jest nieciekawe i nieangażujące, to zachęca do tzw. darmowej jazdy w grupie. Należy zatem usunąć anonimowość oraz przypominać o pewnych standardach zachowania dotyczących danej aktywności (1999, s. 78). Nie bez znaczenia pozostaje wtedy również rywalizacja, którą można zarządzać, odpowiednio stosując system pochwał.

Powyższe grafy wskazują, że w modelu, który za cel stawia sobie aktywizację studenta na zajęciach i poza nimi, ważniejsza staje się motywacja wzrostu. Sukces jest motorem napędzającym uczenie się, dlatego ważne stają się dokładnie 

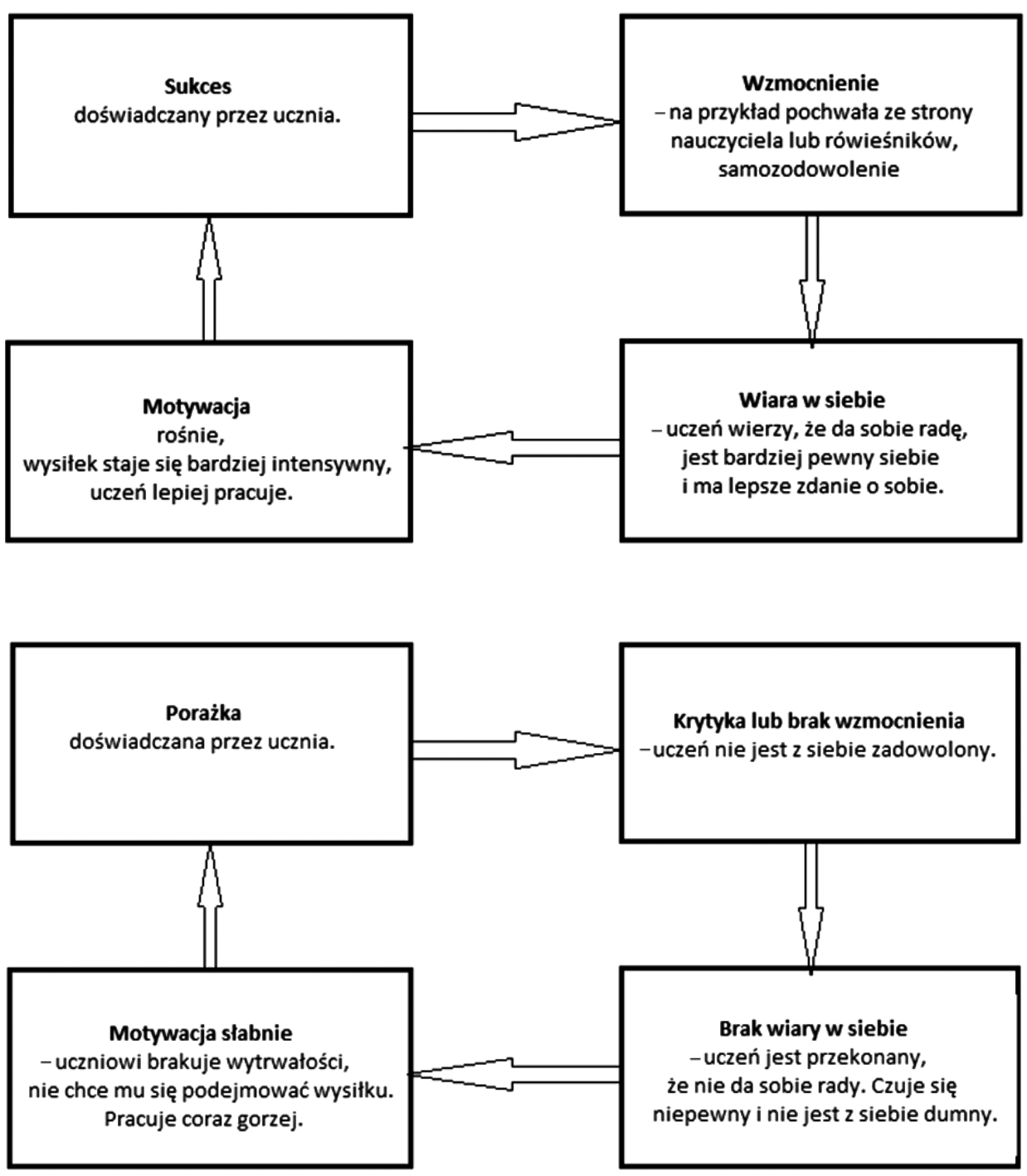

Cykl budujący i niszczący w procesie nauczania.

Za: G. Petty (2010). Nowoczesne nauczanie: praktyczne wskazówki i techniki dla nauczycieli, wykładowców i szkoleniowców. Sopot: Gdańskie Wydawnictwo Psychologiczne, s. 54-54. 
sprecyzowane oczekiwania, różnicowanie poziomu trudności czy podkreślanie celów osobistych. Jednak sama nagroda nie jest wystarczająca, by zmienić postawę studenta. Wykładowcy akademiccy muszą również brać pod uwagę dynamikę grupy, w której pewne normy społeczne mogą tłumić aktywność i sprzyjać nadmiernemu konformizmowi; może też prowokować ona próżniactwo społeczne. Zmiana postawy studenta nie jest rzeczą prostą również dlatego, że nauczyciel akademicki mierzyć się musi z nawykami nabytymi na wcześniejszych etapach nauki. Osiągnięcie motywacji zewnętrznej nie musi więc wcale prowadzić do motywacji wewnętrznej.

Ta pierwsza opiera się przede wszystkim na systemie kar i nagród, druga z kolei nie stawia sobie za cel osiągnięcia zewnętrznych korzyści, wydaje się przez to być autoteliczna, a to, co stanowi jej impuls, nie jest wymierne. Wewnętrzna motywacja wiąże się z Self-Determination Theory (SDT), na którą wpływają głównie dwa czynniki: kompetencje (wiara, że jest się w stanie zakończyć zadanie) oraz autonomia (Newstead, Hoskins, 2003, s. 64). Obie te kwestie rozwijane są w modelu SCL, w którym student przejmuje odpowiedzialność za proces kształcenia. Jak zauważyli Newstead i Hoskins (2003, s. 64), podczas gdy studentów motywowanych wewnętrznie cechuje pogłębione podejście do uczenia się, większa ciekawość, cieszenie się z wyzwań itd., studenci motywowani zewnętrznie koncentrują się na ocenach, aprobacie otoczenia i innych formach zewnętrznej nagrody, utrwalając powierzchowne podejście do nauki (Newstead, Hoskins, 2003, s. 65-66).

Innymi badaniami nad motywacją w szkolnictwie wyższym, potwierdzającymi tezę o roli grywalizacji, są diagnozy socjologiczne Davida Kembera (2016, s. 17-20). Uważa on, że motywacja zależna jest od kontekstu. Badając szkoły w Azji Południowo-Wschodniej, uznał, że na motywację wpływa środowisko uczenia się i nauczania, a nie wewnętrzne właściwości studentów. Dlatego np. motywacja zmienia się na różnych etapach kształcenia - studenci są w stanie efektywniej korzystać z wcześniej zdobytej już wiedzy czy są nastawieni na osiągnięcie konkretnych celów, stąd też wymagają innych sposobów motywowania ich. Te badania wskazują na wpisanie procesu edukacji w przemiany współczesnego świata. Studenci żyją w zglobalizowanej rzeczywistości cyfrowej. Środowisko wirtualne, permanentny tryb online i przerzucenie relacji społecznych na poziom medialny stanowi zarazem pewien potencjał, jak i zagrożenie. Wyzwaniem dla systemu szkolnictwa wyższego jest z pewnością dbanie o kompetencje społeczne i umiejętności interpersonalne czy walka z obniżoną koncentracją, z kolei umiejętności techniczne, rozwój rywalizacji oraz strategiczne podejście do problemów - rozwijane w interaktywnym, zdominowanym przez mechanizmy gier 
otoczeniu - stanowią potencjał, który można wykorzystać wdrażając na zajęciach metody grywalizacji: „Uniwersalnym sposobom podniesienia aktywnej pozycji osoby uczącej się jest »gra«, rozumiana jako aktywna współpraca, której wynik będzie obiektem zainteresowań zarówno nauczyciela, jak i studentów (graczy)” (Kusztina, Zaikin, 2013, s. 121).

\section{POWSZECHNE PRZYCZYNY BRAKU MOTYWACJI WŚRÓD STUDENTÓW}

W kontekście rozważań dotyczących roli właściwego motywowania w procesie nauczania w szkolnictwie wyższym, coraz silniejszą rolę zdaje się odgrywać właśnie grywalizacja, określana również anglojęzycznym terminem gamification lub spolszczonym hasłem gamifikacja. Jedna z wielu definicji w polskiej literaturze przedmiotu dotyczącej tej tematyki określa grywalizację jako „świadome i celowe zastosowanie mechanizmów i technik wykorzystywanych podczas projektowania gier, w celu zwiększania zaangażowania, lojalności, modyfikowania zachowań i przyzwyczajeń ludzi” (Tkaczyk, 2012, s. 10). Inna, autorstwa K.M. Kappa (2012, s. 10), mówi o „wykorzystaniu mechanizmów, estetyki i sposobu myślenia zaczerpniętych z gier, by angażować ludzi, motywować do działania, pobudzać do nauki i rozwiązywania problemów”. Powyższe wyjaśnienia dostarczają także wskazówek dotyczących problemów w motywowaniu studentów, na które odpowiedź stanowić może właśnie grywalizacja jako nowatorska i angażująca metoda dydaktyczna.

Do grona najczęściej diagnozowanych przyczyn braku motywacji wśród studentów, które przezwyciężyć można za sprawą zastosowania techniki grywalizacji w nauczaniu, należą m.in. poczucie znudzenia sposobem przekazywania wiedzy w tradycyjny (podawczy) sposób, powtarzanie złych nawyków i podejść w nauczaniu, wykształconych na wcześniejszych etapach edukacji (Grzymała-Moszczyńska i in., 2013, s. 34-35), brak poczucia realnego sprawstwa w roli podmiotu w procesie nauczania (a nie przedmiotu) (Winnicka-Weis, 2015, s. 61), a także trudności w nawiązywaniu autentycznej i angażującej współpracy w obrębie grupy studentów oraz z prowadzącym zajęcia (Wanner, 2015, s. 145-155). Filozofia SCL wskazała zarys problemów, które obecne są powszechnie w nauczaniu na wszystkich poziomach edukacji, zaś grywalizacja - jako metoda aktywizująca i wpisująca się w nowy paradygmat nauczania - wywołuje w znacznej liczbie analizowanych przypadków wzrost zaangażowania w zdobywanie wiedzy, chęć samodoskonalenia oraz poszerzania naukowych horyzontów (Woźniak, 2015, s. 19-21). 
Jako inne, równie istotne problemy, uniemożliwiające skuteczne pobudzanie motywacji wśród studentów, wskazać można m.in:

- brak angażowania studentów w dyskusję podczas zajęć, a także stosowanie czysto podawczej formy nauczania, bez zadawania pytań, zachęcania do dyskusji w parach bądź grupach oraz unikanie prośby o feedback mający sprawdzić, czy studenci przyswoili poprawnie materiał (Layne, Lake, 2015, s. 256-257);

- zmuszanie studentów podczas wykładów czy ćwiczeń do biernego notowania, zamiast zaproponowania quizów, rozwiązania case study czy obejrzenia materiału filmowego, które pobudziłyby słuchaczy do myślenia i skupiły ich uwagę na prezentowanej tematyce (Layne, Lake, 2015, s. 258);

- brak autentycznego i interpersonalnego zaangażowania ze strony nauczycieli akademickich, ich zdystansowana postawa oraz przejawianie wyraźnego znudzenia prezentowanymi treściami (co wiązać się może z rutyną zawodową) (Belhaj, Abderragman, 2015, s.57-61);

- brak uzyskania przez studentów klarownej informacji zwrotnej w procesie nauczania, trudność w monitorowaniu postępów w nauce (np. przez brak ocen cząstkowych, dostarczania informacji mailowych czy możliwości skonsultowania się z wykładowcą w ramach dodatkowych spotkań) oraz problemy ze zrozumieniem wyników uzyskiwanych w trakcie zaliczania poszczególnych etapów edukacji za sprawą braku jasnych kryteriów oceniania (w ramach przedmiotu czy też jego części) (Woźniak, 2015, s. 18);

- niedostosowanie do kompetencji studentów trudności materiału wymaganego do przyswojenia, co powoduje często zniechęcenie i znaczny spadek motywacji wśród osób pracujących wolniej niż grupa (Woźniak, 2015, s. 19);

- niespójny kształt kursu akademickiego, mała przydatność zdobytej podczas studiów wiedzy i umiejętności na rynku pracy oraz niedopasowanie treści kształcenia do realiów zawodowych w Polsce (O stanie szkolnictwa..., 2011, s. 3);

- konieczność łączenia wielu czynności (aktywności uczelnianych ze stażami, praktykami, dodatkowymi kursami językowymi czy hobby) oraz ról jednocześnie (głównie życia rodzinnego i zawodowego z uczelnianym) (Wróblewska, 2012, s. 73-74).

Choć wymienione powyżej czynniki powodujące brak motywacji mogą być różnorodne i częstokroć trudne do przezwyciężenia, jak podkreśla Biggis (1999, s. 61), „motywacja jest efektem dobrego nauczania, a nie warunkiem wstępnym”, co wskazuje na możliwość pokonania trudności i zmianę podejścia do braku 
motywacji wśród uczniów i studentów. Ogromną szansę na to stanowi właśnie grywalizacja - stosowana umiejętnie jako metoda dydaktyczna, pozwala na potencjalne przezwyciężenie szeregu problemów w obrębie problematyki motywowania osób uczących się.

\section{GRYWALIZACJA JAKO SPOSÓB RADZENIA SOBIE Z BRAKIEM MOTYWACJI WŚRÓD STUDENTÓW}

Jedną z grup metod promowanych przez SCL są narzędzia dydaktyczne oparte o gry i współzawodnictwo. Coraz większą popularność w dydaktyce zyskują metody pracy wykorzystujące właśnie dynamikę i mechanikę gier (ang. Game Based Learning (GBL) lub edugaming). Zarówno większość pedagogów, jak i projektantów gier zgadza się ze stwierdzeniem, że współcześnie gry mają wysoki potencjał w procesie uczenia się i mogą sprawić, że nauka będzie przypominać zabawę. Jak uważa Koster (2004, s. 110-116), „dzięki grom chęć nauki może być jak narkotyk".

Nietrudno udowodnić, że organizacja kursów akademickich sama w sobie przypomina mechanizmem grę, dlatego możliwe i potencjalnie łatwe jest skorzystanie z jej mechanizmów przy projektowaniu zajęć. Na poniższym schemacie student został przedstawiony jako gracz, kurs akademicki jako poziom w grze (ang. level), zadania jako wyzwania, oceny jako punkty, zaś zaliczenie jako wygrana (Pirker, Gutl, 2015, s. 262).

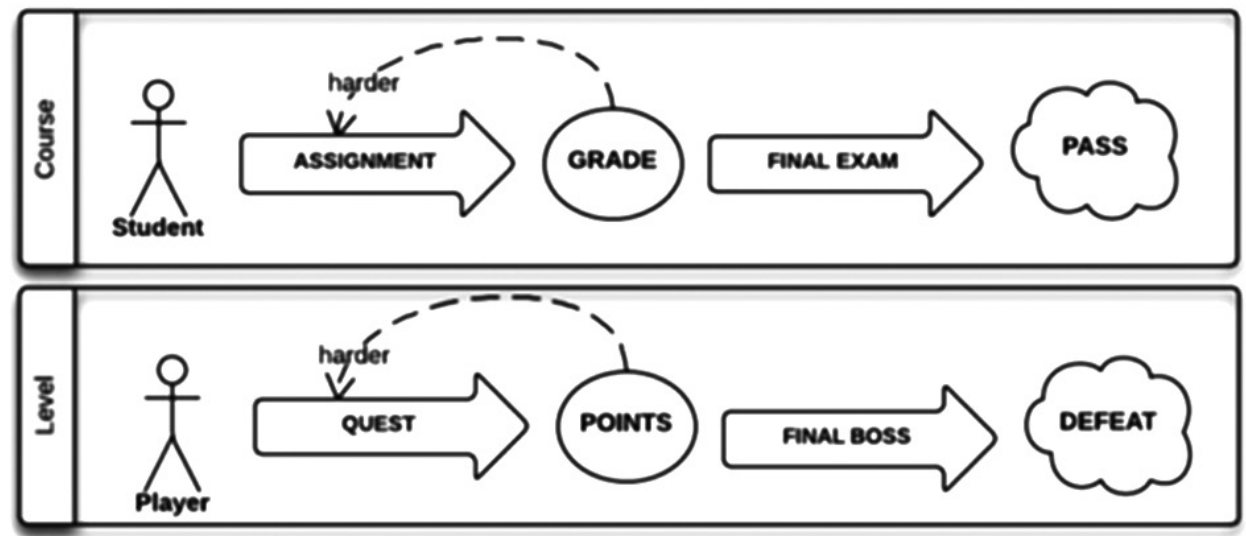

Tradycyjne zajęcia swoją organizacją często przypominają mechanikę gry.

Pirker, J. (2013). Virtual TEAL World. Master Thesis, Graz University of Technology. 
Stosowanie mechanizmów gry w procesie dydaktycznym może służyć rozwijaniu środowiska sprzyjającego uczeniu się poprzez zapewnienie studentom możliwości empirycznego doświadczania, a co najważniejsze, pobudzania autentycznego zainteresowania studentów zajęciami, co powoduje wzrost motywacji do nauki (Stricland, Kayloe, 2016, s. 101-103). Wynika z tego, iż korzystanie z mechaniki gier w nauczaniu podnosi u studentów poziom zaangażowania w proces grywalizacyjny, pomimo że uczenie się w oczach gracza ma charakter uboczny (Bołtuć, Bołtuć, 2004).

Wybrane polskie oraz zagraniczne badania z zakresu grywalizacji jako metody dydaktycznej w środowisku akademickim potwierdzają dużą skuteczność korzystania z mechaniki gier w procesie uczenia się. Jeden z przykładów stanowić może wdrożenie projektu „Wyścig po sukces studentów pielęgniarstwa” (ang. The Race for Nursing Student Success), w którym studentom tego kierunku na Uniwersytecie w Alabamie zorganizowano zajęcia przy użyciu mechanizmów gier - taka forma zajęć poskutkowała wzrostem opanowania materiału o 15\% w porównaniu z wynikami z poprzedniego roku (Strickland, Kaylor, 2016, s. 101-103). Na terenie kampusu zorganizowano dla studentów grę, odbywającą się przez cały semestr, która wykorzystywała formułę meczu futbolowego. W rozmaitych lokalizacjach grupy studentów miały do zrealizowania różne merytoryczne zadania, realizacja których zapewniała im punkty, zapisywane na tablicy wyników. Poza wartością dodaną w postaci zwiększenia efektywności nauki, studenci bardzo pozytywnie wypowiadali się o zaproponowanej formie zdobywania wiedzy, podkreślając, że spowodowała ona znaczący wzrost motywacji i zaangażowania (Strickland, Kaylor, 2016, s. 101-103).

W innym z analizowanych przypadków zastosowania grywalizacji w szkolnictwie wyższym pozytywne wyniki nauczania osiągnęli organizatorzy kursu dla inżynierów przemysłowych w Brazylii. Studenci otrzymywali zadania do wykonania za pomocą platformy internetowej. Zadania dotyczyły projektowania prototypów przemysłowych, ale przy ich realizacji kursanci musieli nabyć wiedzę odpowiadającą celom dydaktycznym programu. Po zakończeniu programu przeprowadzono ewaluację, z której wynikało, że studenci - bardziej niż w przypadku tradycyjnej edukacji - zostali zmotywowani do pracy i lepiej przyswoili wiedzę merytoryczną.

Elementy grywalizacji mogą strukturyzować również tradycyjne zajęcia w innej formule niż omówione powyżej przykłady. W tomie Global Innovation of Teaching and Learning in Higher Education: Transgressing Boundaries pojawiają się dwa niezwykle interesujące sposoby budowania motywacji zewnętrznej i wewnętrznej za pomocą gier - tak w przypadku MMORPG (Massively Multiplayer Online Role 
Playing Games), które wykorzystuje się efektywnie do nauki języka obcego, jak i Lego Serious Play, rozwijającej pracę w grupie (Layne, Lake, 2015). To tylko dwa przykłady z szeregu licznych, znanych w literaturze przedmiotu, które ukazują, że grywalizacja pozwala rozwijać cechy hormetyczne wśród studentów.

Badacze zajmujący się Game Based Learning podkreślają jeszcze jedną istotną zaletę wykorzystywania tej metody w dydaktyce. Uczestnicy tego rodzaju zajęć mogą podejmować działania symulujące ich rzeczywiste zawodowe obowiązki, ale podczas gry odbywa się to w zupełnie bezpiecznym środowisku (Mawhirter, Garofalo, 2016, s. 132-136). Dokładniej rzecz ujmując, symulowanie rzeczywistości w grze pozwala się uczyć unikając lub zmniejszając ryzyka i konsekwencje, które mogłyby zaistnieć w rzeczywistości (Gee, 2003), co może znacznie poprawiać komfort nauki wśród osób borykających się z brakiem pewności siebie oraz wymagających przyjęcia indywidualnego tempa pracy.

\section{PODSUMOWANIE}

Przedstawiona w artykule problematyka motywowania studentów za pomocą stosowania techniki grywalizacji w procesie nauczania wskazała zarówno szereg problemów i wyzwań, z którymi mierzą się nauczyciele akademiccy oraz studenci, jak i praktyczne sposoby radzenia sobie z niską motywacją wśród osób uczących się. Grywalizacja jako stosunkowo atrakcyjna i obiecująca metoda dydaktyczna, wpisująca się w nurt filozofii SCL, niesie szansę na zaktywizowanie współczesnej młodzieży akademickiej za pomocą sposobów przekazywania wiedzy adekwatnych do ich oczekiwań i umiejętności, a także uwarunkowań kulturowych XXI wieku, które obejmują m.in. rosnący postęp technologiczny, cyfryzację oraz wykorzystywanie interaktywnych narzędzi w praktycznie wszystkich wymiarach współczesnego życia. Mechanizmy gry stosowane w procesie dydaktycznym pozwalają na przyjęcie formuły przekazywania wiedzy, która jest przyjazna dla studentów (angażująca, pobudzająca umysł do pracy, rządząca się zasadami podobnymi jak gry komputerowe czy planszowe) oraz nauczycieli akademickich (zapewniając im możliwość korzystania z interaktywnych technologii, efektywnego sprawdzania postępów w nauczaniu oraz budowania dobrych relacji ze studentami, co ułatwia znacząco współpracę podczas zajęć). Rywalizacja, określana również mianem współzawodnictwa, jest esencjonalnym elementem grywalizacji jako metody nauczania, co stanowi również o jej dużej skuteczności. Jak wskazali autorzy niniejszego artykułu, motywowanie jest niezwykle ważnym elementem w procesie nauczania, który można jednak stopniowo wypracowywać, kierując się zasadami 
współpracy pomiędzy obiema stronami procesu nauczania, a także konsekwencją i chęcią zmiany dotychczasowego paradygmatu edukacyjnego, zakładającego stosowanie metod podawczych. Podstawą grywalizacji jest motywowanie, które wymaga podjęcia intensywnego i autentycznego wysiłku przez studentów i nauczycieli akademickich, który zaowocować może bardziej efektywnym przyswojeniem materiału, pobudzeniem wśród studentów autentycznej pasji do nauki, a także zbudowaniem pozytywnych relacji pomiędzy wykładowcą a studentami, co jest również jedną z kluczowych wartości cenionych w kulturze akademickiej (Cewińska, Krasnva, 2014, s. 76-81). Grywalizacja, zastosowana umiejętnie i zaprojektowana w atrakcyjny sposób, może stanowić rozwiązanie wielu problemów, z którymi boryka się współczesna edukacja akademicka w Polsce oraz na świecie.

\section{Literatura:}

Baeten, M., Dochy, F., Struyven, K., Parmentier, E., Vanderbruggen, A. (2016). Student-centred learning environments: an investigation into student teachers' instructional preferences and approaches to learning. Learning Environments Research, 1 (19), s. 43-62.

Belhaj, A.N., Ben Abderrahman, M.L. (2015). The Portrait of “Good University Teacher” as Perceived by Tunisian Students. International Journal of Higher Education, 4 (3), s. 57-62.

Biggis, J. (1999). What the student does: teaching for enchanced learning. Higher Eduaction Research and Development, 1 (18), s. 57-75.

Bołtuć, M., Bołtuć, P. (2004). Inne spojrzenie na nauczanie w oparciu o gry. „E-mentor”, 2 (4). Pobrane z: http://www.e-mentor.edu.pl/artykul/index/numer/4/id/43.

Cewińska, J., Krasnova, A. (2014). Grywalizacja w rozwoju i edukacji - szanse i zagrożenia. Prace Naukowe Uniwersytetu Ekonomicznego we Wrocławiu, 350, s. 73-81.

Gee, J.P. (2003). Learning principles. What video games have to teach us about learning and literacy. Computers in Entertainment (CIE) - Theoretical and Practical Computer Applications in Entertainment, 1. Pobrane z: http://cie.acm.org/articles/what-videogames-have-to-teach-us-about-learning-and-literacy.

Geen, R.G. (1999). Motywacja społeczna. W: B. Parkinson, A.M. Colman (red.), Emocje i motywacja (s. 61-84). Poznań: Zysk i S-ka.

Grzymała-Moszczyńska, J., Kwiecień, K., Rataj, A., Barzykowski, K. (2013). Stan wdrożenia modelu nauczania skoncentrowanego na studentach i studentkach na polskich uczelniach wyższych. Nauka i Szkolnictwo Wyższe, 2, s. 32-49.

Kapp, K.M., (2012). The Gamification of Learning and Instruction: Game-Based Methods and Strategies for Training and Education. San Francisco: Pfeiffer.

Kember, D. (2016). Understanding the Nature of Motivation and Motivating Students through Teaching and Learning in Higher Education. Singapore-Heidelberg-New York-Dordrecht-London: Springer. 
Koster, R. (2004). A theory of fun for game design, Sebastopol: Paraglyph Press.

Kusztina, E., Zaikin, O., Żyławski, A., Tadeusiewicz, R. (2013). Model motywacji nauczyciela i studentów podczas nabywania kompetencji. Zeszyt Naukowy Warszawskiej Wyższej Szkoły Informatyki, 9, s. 119-137.

Layne, C.P., Lake, P. (red.), (2015). Global Innovation of Teaching and Learning in Higher Education, Cham-Heidelberg-New York-Dordrecht-London: Springer.

Marshall, J., Fayombo, G, Marshall, R. (2015). I Paid for It, so I Deserve It! Examining Psycho-Educational Variables and Student Consumerism Attitudes to Higher Education. International Journal of Higher Education, 4 (4), s. 73-80.

Mawhirter, D.A., Garofalo, P.F. (2016). Expect the Unxepected: Simulation Games as a Teaching Strategy. Clinical Simulation in Nursing, 12, s. 132-136.

Newstead, S.E., Hoskins, S. (2003). Encouraging student motivation. W: H. Fry, S. Ketteridge, S. Marshall (red.), A Handbook for Teaching \& Learning in Higher Education. London-Sterling: Kogan Page.

O stanie szkolnictwa wyższego i źródłach jego finansowania (2011). Komunikat z Badań CBOS. Pobranie z: http://www.cbos.pl/SPISKOM.POL/2011/K_012_11.PDF.

Petty, G. (2010). Nowoczesne nauczanie: praktyczne wskazówki i techniki dla nauczycieli, wykładowców i szkoleniowców. Sopot: Gdańskie Wydawnictwo Psychologiczne.

Pirker, J., Gutl, C. (2015). Educational Gamified Science Simulations. W: T. Reiners, L. Wood (red.), Gamification in Education and Business (s. 253-276). Cham-Heidelberg-New York-Dordrecht-London: Springer.

Riesman, D. (2011). Samotny tłum. Kraków: Wydawnictwo vis-à-vis/Etiuda.

Strickland, H.P., Kaylor, S.K. (2016). Bringing your a-game: Educational gaming for student success. Nurse Education Today, 40, s. 101-103.

Tkaczyk, P. (2012). Grywalizacja. Jak zastosować mechanizmy gier w działaniach marketingowych. Gliwice: Wydawnictwo HELION.

Wanner, T. (2015). Enhancing Student Engagement and Active Learning through Just-in-Time Teaching and the use of PowerPoint. International Journal of Teaching and Learning in Higher Education, 27, s. 154-163.

Winnicka-Wejs, A. (2015). Motywowanie do rozwoju z zastosowaniem grywalizacji. Zarządzanie Zasobami Ludzkimi, 3-4, s. 57-80.

Woźniak, J. (2015). Grywalizacja w zarządzaniu ludźmi. Zarządzanie Zasobami Ludzkimi, 2 (103), s. 11-33.

Wróblewska, W. (2012). Metody pracy ze studentami w kontekście efektów określonych w Krajowych Ramach Kwalifikacji dla Szkolnictwa Wyższego. E-mentor, 1 (43). Pobrano z: http://www.e-mentor.edu.pl/artykul/index/numer/43/id/897.

Zimbardo, P.G. (1988). Psychologia i życie. Warszawa: PWN. 